\title{
The Divergent Homeobox Gene PBX1 Is Expressed in the Postnatal Subventricular Zone and Interneurons of the Olfactory Bulb
}

\author{
Lori Redmond, ${ }^{1}$ Susan Hockfield, ${ }^{1}$ and Maria A. Morabito ${ }^{2}$ \\ 1Section of Neurobiology, and 'Department of Pharmacology, Yale University School of Medicine, New Haven, \\ Connecticut 06520-8066
}

In the mammalian brain, an important phase of neurogenesis occurs postnatally in the subventricular zone (SVZ). This region consists of a heterogeneous population of cells, some mitotically active, others postmitotic. A subset of mitotically active SVZ precursor cells gives rise to a population of neurons that migrates over a long distance to their final destination, the olfactory bulb. Other SVZ precursor cells continue to proliferate or undergo cell death. The combination of genes that regulates proliferation and cell fate determination of SVZ precursor cells remains to be identified. We have used the rat homolog of the human homeobox gene $P B X 1$ in Northern analysis and in situ hybridization studies to determine the temporal and regional localization of $P B X 1$ expression during embryonic and postnatal rat brain development. $P B X 1$ is expressed embryonically in the telencephalon. In addition, it is expressed at high levels postnatally in the SVZ, in the migratory pathway to the olfactory bulb, and in the layers of the olfactory bulb that are the targets of these migratory neurons. Combining in situ hybridization for $P B X 1$ with immunostaining for markers of cell proliferation (PCNA), postmitotic neurons (class III $\beta$-tubulin), and glia (GFAP), we show that SVZ proliferating cells and their neuronal progeny express rat $P B X 1$ mRNA, whereas glial cells do not express detectable levels of $P B \times 1$. The expression of $P B X 1$ in SVZ precursor cells and postmitotic neurons suggests a role for $P B X 1$ in the generation of olfactory bulb interneurons and in mammalian neurogenesis.

Key words: development; differentiation; PBX1; homeobox gene; transcription factor; neurogenesis; precursor cell; subventricular zone; forebrain; olfactory bulb
Although in the rat a majority of neurons are born embryonically, distinct populations of neurons are generated postnatally from precursor cells in the subventricular zone (SVZ) (Altman, 1969; Lois and Alvarez-Buylla, 1993, 1994; Luskin, 1993). The SVZ derives from the embryonic ventricular zone and expands in late gestation and early postnatal life, and a remnant of this region persists into adult life. This proliferative zone contains a heterogeneous population of cells, including stem cells, mitotically active precursor cells, and postmitotic neurons (Morshead and van der Kooy, 1992; Reynolds and Weiss, 1992; Lois and Alvarez-Buylla, 1993; Menezes and Luskin, 1994; Morshead et al., 1994). The fate of the precursor cells is either cell death or differentiation into neurons or glia (Morshead and van der Kooy, 1992; Reynolds and Weiss, 1992; Levison and Goldman, 1993; Lois and AlvarezBuylla, 1993, 1994; Luskin, 1993). Many postmitotic cells generated in the SVZ migrate into the overlying cortex. However, a population of postmitotic neurons generated in the anterior SVZ migrates rostrally along a well described pathway to the olfactory bulb where the cells differentiate into granule and periglomerular neurons (Kishi, 1987; Luskin, 1993; Lois and Alvarez-Buylla, 1994).

Cell fate determination undoubtedly requires the activation of

\footnotetext{
Received Aug. 30, 1995; revised Feb. 2, 1996; accepted Feb. 12, 1996.

This work was supported by a National Institutes of Health grant to S.H. and the U.S. Army Medical Research and Development Command. We thank Edward Moczydlowski for support throughout this project, Pietro de Camilli for the cDNA library, Anthony Frankfurter for antibody to class III $\beta$-tubulin, Thom Hughes for help with the photography, and Charles A. Greer for helpful comments on this manuscript.

Correspondence should be addressed to Dr. Maria A. Morabito, Department of Pharmacology, Yale University School of Medicine, P.O. Box 208066, 333 Cedar Street, New Haven, CT 06520-8066.

Copyright (C) 1996 Society for Neuroscience 0270-6474/96/162972-11\$05.00/0
}

many genes, some of which have been identified as members of distinct classes of transcription factors such as the homeodomain proteins (Gruss and Walther, 1992; Treacy and Rosenfeld, 1992; Boncinelli, 1994; Rubenstein and Puelles, 1994; Alvarez-Bolado et al., 1995). One recently identified subclass of homeodomain proteins contains a homeodomain highly divergent from those previously reported, and only $36 \%$ identical to the homeodomain of yeast MATa1 (Kamps et al., 1990; Nourse et al., 1990; Monica et al., 1991). One of these, the human proto-oncogene $P B X 1$, was originally identified as part of the $t(1 ; 19)$ translocation protein found in pre-B cell acute lymphoblastic leukemias (Kamps et al., 1990; Nourse et al., 1990). Extradenticle (exd), the Drosophila homolog of $P B X 1$, is not closely related to any other known Drosophila homeodomain proteins (Flegel et al., 1993; Rauskolb et al., 1993). Both exd and the mammalian $P B X$ homeodomains contain a three-amino-acid insertion that is absent from other known homeodomains, but is present in the yeast protein MAT $\alpha 2$. Although not exclusive to the nervous system, $P B X 1$ is abundantly expressed in the developing rat brain (Roberts et al., 1995). $P B X 1$ is also expressed at high levels in human fetal brain; the two other known members of this family, $P B X 2$ and $P B X 3$, are expressed at lower levels in brain (Monica et al., 1991). In the present study, we report the temporal and the regional localization of $P B X 1$ expression during late embryonic and postnatal rat brain development. $P B X 1$ expression in the embryonic telencephalon and the postnatal proliferative zone, the subventricular zone, argues for a role for $P B X 1$ in mammalian neurogenesis and, in particular, in the generation of the olfactory bulb interneurons.

\section{MATERIALS AND METHODS}

cDNA cloning and characterization. The sense (5'-GCCTGCAACGAGTTCACCACCCACG-3') and the antisense (5'-GGCTTCCTCACTG- 
GGGTAAGGG-3') oligonucleotides flanking the homeobox sequence of human $P B X 1$ were used to isolate a cDNA fragment from an adult rat brain cDNA library by PCR amplification. PCR reactions were performed for 30 cycles of $94^{\circ} \mathrm{C}$ for $1 \mathrm{~min}, 42^{\circ} \mathrm{C}$ for $1 \mathrm{~min}$, and $72^{\circ} \mathrm{C}$ for $2 \mathrm{~min}$, using Taq DNA polymerase (Perkin-Elmer, Branchburg, NJ). The PCR product was subcloned into pCR-II vector using the TA cloning kit (InvitrogeII, Sanl Diego, CA), and its sequence was determined by the dideoxy chain termination method (Sequenase, Stratagene, La Jolla, CA). The PCR-derived clone, corresponding to residues 172-267 of human $P B X 1$, was then used to screen an adult rat brain cDNA library by standard procedures (Maniatis et al., 1989). A partial rat cDNA clone corresponding to residues $44-386$ of the human PBX1 homeoprotein was isolated, characterized, sequenced, and used as probe in Northern blot analysis. An EcoRI fragment preceding the homeobox sequence and corresponding to residues 44-176 was subcloned in pBluescript and used to generate in situ hybridization probes.

Preparation of RNA and Northern analysis. Total RNA was isolated from various regions of the brain and at different ages using the method described by Chomczynski and Sacchi (1987). Approximately $10 \mu \mathrm{g}$ of total RNA isolated from the indicated tissues was fractionated on $1.2 \%$ formaldehyde-agarose gels, transferred to a positively charged nylon membrane (Hybond ${ }^{+}$, Amersham, Arlington Heights, IL), and hybridized to a random-primed ${ }^{32} \mathrm{P}$-labeled rat $P B X 1$ cDNA fragment corresponding to residues 44-386 of the human PBX1 homeoprotein. Hybridizations were carried out in $5 \times \mathrm{SSC}, 0.5 \% \mathrm{SDS}, 5 \times$ Denhardt's solution, and $0.2 \mathrm{mg} / \mathrm{ml}$ salmon sperm DNA at $65^{\circ} \mathrm{C}$ for at least $16 \mathrm{hr}$, and high-stringency washes were done in $0.1 \times \mathrm{SSC}, 0.5 \%$ SDS at $60^{\circ} \mathrm{C}$. Consistent results were obtained when the original PCR clone and the EcoRI fragment not encoding the homeodomain were used as probes (data not shown). Hybridization for cyclophilin was used as a control for equal loading of RNA of brain tissues (Danielson et al., 1988).

In situ hybridization. Rat $P B X 1$ sense and antisense riboprobes were transcribed from the $398 \mathrm{nt} E c o$ RI fragment encoding a region preceding the homeodomain, subcloned in pBluescript. Antisense riboprobe was synthesized by T3 polymerase from $X b a I$-digested plasmid. Sense transcripts were synthesized from KpnI-linearized plasmid by T7 polymerase. In situ hybridization was performed as described previously (Jaworski ct al., 1994). Sections $12-14 \mu \mathrm{m}$ thick were fixed in $4 \%$ paraformaldehyde in phosphate-buffered solution, acetylated, slowly dehydrated, and delipidated in chloroform. After prehybridization at $50^{\circ} \mathrm{C}$ for $1 \mathrm{hr}$ in $2 \times \mathrm{SSC}$, $50 \%$ formamide, the sections were hybridized at $50^{\circ} \mathrm{C}$ for $16 \mathrm{hr}$ in $0.75 \mathrm{M}$ $\mathrm{NaCl}, 50 \%$ formamide, $1 \times$ Denhardt's, $10 \%$ dextran sulfate, $30 \mathrm{~mm}$ dithiothreitol (DTT), and $0.5 \mathrm{mg} / \mathrm{ml}$ yeast tRNA with $2 \times 10^{7} \mathrm{cpm} / \mathrm{ml}$ $\left[{ }^{35} \mathrm{~S}\right] \mathrm{CTP}$-labeled riboprobe. After hybridization, sections were washed in $2 \times \mathrm{SSC}, 50 \%$ formamide, $0.1 \% \beta$-mercaptoethanol (BME) at $50^{\circ} \mathrm{C}$ for 1 $\mathrm{hr}$ and treated with $20 \mu \mathrm{g} / \mathrm{ml}$ RNase $\mathrm{A}$ at $37^{\circ} \mathrm{C}$ for $30 \mathrm{~min}$. Slides were then washed in $2 \times \mathrm{SSC}, 50 \%$ formamide, $0.1 \% \mathrm{BME}$ at $58^{\circ} \mathrm{C}$ for $30 \mathrm{~min}$ and at high-stringency in $0.1 \times \mathrm{SSC}, 0.1 \% \mathrm{BME}$ at $63^{\circ} \mathrm{C}$ for $30 \mathrm{~min}$. Slides were dehydrated and exposed to Hyperfilm (Amersham) for 5-14 d, then coated with Kodak NTB-2 nuclear track emulsion. After 5-12 d, the sections were developed with Kodak D-19, fixed with Kodak Rapid Fix and, in some cases, counterstained with cresyl violet. Near-adjacent sections were hybridized with probes corresponding to the middle subunit of neurofilament and the sense strand of $P B X I$ as positive and negative controls, respectively.

Immunohistochemistry combined with in situ hybridization. In situ hy bridization was performed as described above with two modifications: the sections were sliced $10 \mu \mathrm{m}$ thick, and delipidation in chloroform was omitted. After the washes, the sections were dehydrated, washed in PBS, preincubated in blocking solution $[2 \% \mathrm{BSA}, 0.1 \%$ Triton X-100 in PBS, pH 7.4 (PCNA, GFAP) or 5\% FCS, $0.1 \%$ Triton X-100 in DMEM (TuJ1)] and then incubated with a primary antibody diluted in blocking serum at $4^{\circ} \mathrm{C}$ overnight. The primary antibodies used for this study were: mouse anti-PCNA (Boehringer Mannheim, Indianapolis, IN) at a 1:100 dilution, mouse antibody to class III $\beta$-tubulin (a neuron-specific isotype) (clone TuJ1, a gift of A. Frankfurter, University of Virginia, Charlottesville, VA) at a 1:2500 dilution, and mouse anti-GFAP (Sigma, St. Louis, MO) at a 1:3000 dilution. Sections were washed in PBS, incubated for 2 hr with biotinylated secondary antibody (Vector Laboratories, Burlingame, CA) at a 1:200 dilution in blocking serum at room temperature, washed in PBS, and incubated in a 1:200 dilution of avidin-biotinhorseradish peroxidase (HRP) complex for $1 \mathrm{hr}$ at room temperature. The HRP reaction was visualized using diaminobenzidine $(0.25 \mathrm{mg} / \mathrm{ml})$ and $\mathrm{H}_{2} \mathrm{O}_{2}(0.003 \%)$. For control sections, the primary antibody was omitted. After immunolabeling, the sections were dehydrated and processed for autoradiography as described above.

Immunohistochemistry combined with in situ hybridization on dissociated cells. SVZ and olfactory bulbs of postnatal day 6 (P6) rats were collected in HBSS (Gibco, Grand Island, NY) and incubated in $0.025 \%$ trypsinEDTA (Gibco), $20 \mu \mathrm{g} / \mathrm{ml}$ DNase I at $37^{\circ} \mathrm{C}$ for $30 \mathrm{~min}$. Excess DMEM supplemented with F12 (DMEM/F12; Gibco) and protease inhibitors [0.1 mM leupeptin (Amersham), $400 \mathrm{U} / \mathrm{ml}$ aprotinin (Sigma), $4 \mu \mathrm{M}$ pepstatin A (Boehringer Mannheim)] were added, and cells were dissociated by trituration. Cells were washed in DMEM/ $/ 2$ supplemented with protease inhibitors and $20 \mu \mathrm{g} / \mathrm{ml}$ DNase I and plated in DMEM/F12 at a density of $1 \times 10^{4}$ cells $/ \mathrm{ml}$ on coverslips coated with $10 \mu \mathrm{g} / \mathrm{ml}$ poly-Llysine (molecular weight $=150,000-300,000 ;$ Sigma) and $10 \mu \mathrm{g} / \mathrm{ml} \mathrm{lami-}$ nin (Sigma). Cells were then incubated at $37^{\circ} \mathrm{C}$ for $60-75$ min to allow cells to attach to the substrate. Subsequently, coverslips were rinsed in PBS then fixed for $15 \mathrm{~min}$ in $4 \%$ paraformaldehyde, $4 \%$ sucrose in PBS (warmed to $37^{\circ} \mathrm{C}$ ). Coverslips were then rinsed in PBS and dehydrated in $70 \%$ ethanol. Before hybridization, fixed cells were washed for $10 \mathrm{~min}$ at room temperature in PBS containing $5 \mathrm{mM} \mathrm{MgCl}_{2}, 10 \mathrm{~min}$ in $0.2 \mathrm{M}$ Tris with $0.1 \mathrm{M}$ glycine, $\mathrm{pH} 7.4$, and $10 \mathrm{~min}$ in $2 \times \mathrm{SSC}, 50 \%$ formamide at $60^{\circ} \mathrm{C}$. In situ hybridization was performed as described above with some modifications: the cells were prehybridized in hybridization buffer without DTT and yeast tRNA for $1 \mathrm{hr}$ at $50^{\circ} \mathrm{C}$, and the hybridization was conducted wilh $4 \times 10^{7} \mathrm{cpm} / \mathrm{ml}\left[{ }^{35} \mathrm{~S}\right] \mathrm{CTP}$-labeled riboprobe. After hybridization, coversiips were washed twice in $2 \times$ SSC, 1 mM EDTA, $0.1 \%$ $\mathrm{BME}$ for $10 \mathrm{~min}$ and treated with $2 \mu \mathrm{g} / \mathrm{ml}$ RNase $\mathrm{A}$ at $37^{\circ} \mathrm{C}$ for $30 \mathrm{~min}$ in $500 \mathrm{~mm} \mathrm{NaCl}, 10 \mathrm{~mm}$ 'l'ris, pH 8.0. Coverslips were then washed twice in $2 \times \mathrm{SSC}, 1 \mathrm{~mm}$ EDTA, $0.1 \% \mathrm{BME}$ for $10 \mathrm{~min}$ and at high-stringency in $0.1 \times \mathrm{SSC}, 1 \mathrm{~mm}$ EDTA, $0.1 \% \mathrm{BME}$ at $55^{\circ} \mathrm{C}$ for $1 \mathrm{hr}$, followed by two 5 min washes in $0.5 \times \mathrm{SSC}$. After the washes, the coverslips were treated for immunohistochemistry as described previously. The primary antibodies were used at higher concentrations: mouse anti-PCNA (1:50 dilution) and mouse antibody to class III $\beta$-tubulin (1:1250 dilution). The HRP reaction product was enhanced with $0.06 \%$ nickel ammonium sulfate. For control sections, the primary antibody was omitted. After immunolabeling, the sections were dehydrated and processed for autoradiography as described above.

\section{RESULTS}

\section{Identification of rat $P B X 1$}

To investigate the regional distribution of $P B X 1$ expression in the developing CNS and its potential role in mammalian neurogenesis, a partial cDNA clone corresponding to rat $P B X 1$ was isolated. Initially, a cDNA fragment was amplified from an adult rat brain cDNA library using PCR with primers derived from the DNA sequences flanking the homeobox region of human $P B X 1$. The product of the reaction, a $400 \mathrm{bp}$ cDNA, was cloned and its identity as a $P B X 1$ homolog confirmed by DNA sequencing. This PCR product was used as a probe to screen an adult rat brain cDNA library. The isolated cDNA is $\sim 1.5 \mathrm{~kb}$ in length, includes the homeobox domain, and represents the rat homolog of human $P B X 1$ (data not shown). A derived EcoRI fragment, corresponding to residues 44176 of the human $P B X 1$ and preceding the homeodomain (Fig. 1A), was subcloned in the pBluescript plasmid to synthesize $P B X 1$-specific riboprobes. This cDNA fragment is $70 \%$ identical to Drosophila exd, and its derived amino acid sequence is $83 \%$ identical to the exd protein (Flegel et al., 1993; Rauskolb et al., 1993). Furthermore, this cDNA fragment is 92 and $97 \%$ identical to the human $P B X 1$ homolog at the nucleotide (Fig. $1 B$ ) and amino acid level, respectively, and has only $77-79 \%$ nucleotide identity with the closely related human $P B X 2$ and $P B X 3$ genes (Monica et al., 1991). In all Northern analyses, the rat $P B X 1$ probes hybridized specifically to a band of $\sim 8 \mathrm{~kb}$ (Fig. $1 C$ ), similar in size to the $7.6 \mathrm{~kb}$ human $P B X 1$ transcript (Monica et al., 1991). Identical results were obtained using the PCR-derived clone corresponding to residues 172-267 and the EcoRI fragment corresponding to residues $44-176$ of the human gene (data not shown). 


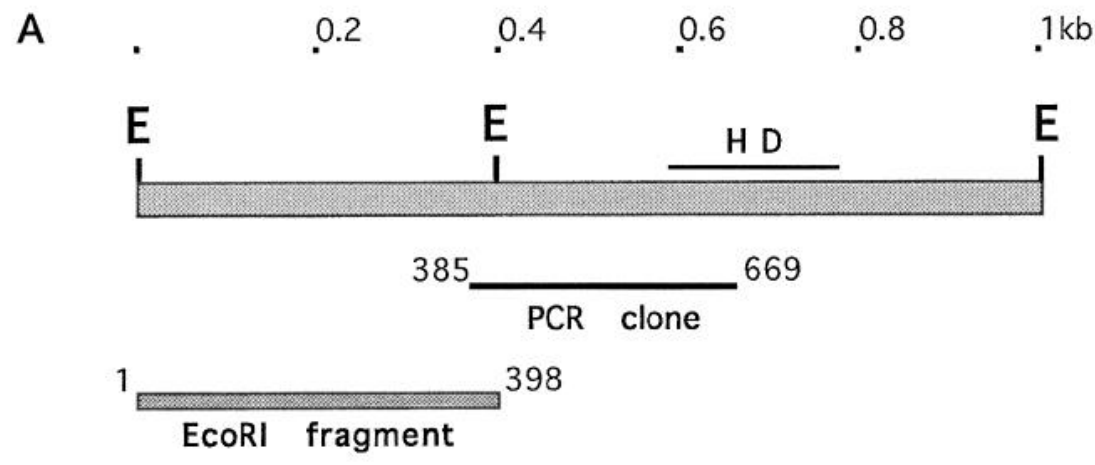

\section{B} rat PBX1 CCGGGGACATTTTACAGCAAATTATGACCATCACAGACCAGAGTTTGGATGAAGCGCAGG 60 hum PBX1 TTGGAGACATTTTACAGCAAATTATGACCATCACAGACCAGAGTTTGGATGAGGCGCAGG 310
CCAGAAAACATGCTTTAAACTGCCACAGAATGAAGCCTGCCTTGTTTAATGTGTTGTGTG 120

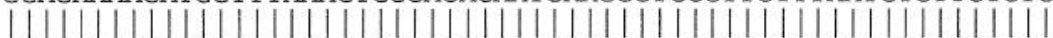
CCAGAAAACATGCTTTAAACTGCCACAGAATGAAGCCTGCCTTGTTTAATGTGTTGTGTG 370

AAATCAAAGAAAAAACAGTTTTGAGTATTCGGGGAGCCCAAGAGGAGGAGCCCACAGAGC 180

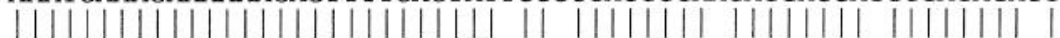
AAATCAAAGAAAAAACAGTTTTTGAGTATCCGAGGAGCCCAGGAGGAGGAACCCACAGACC 430

CCCAGCTCATGCGACTGGACAACATGCTGCTAGCAGAAGGGGTGGCGGGGCCTGAGAAGG 240

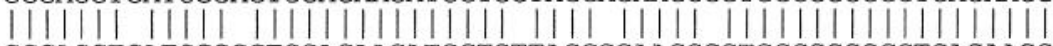
CCCAGCTGATGCGGCTGGACAACATGCTGTTAGCGGAAGGCGTGGCGGGGCCTGAGAAGG 490

GCGGAGGCTCंGGCAGCGGCÄGCGGCAGCAGCGGCAGCTTCTGGGGGTGCAंGGTTCAGACA் 300 |||||||||||||||||||||||||||||||||||||||||||||||||| GCGGAGGGTCGGCGGCAGCGGCGGCAGCGGCGGCGGCTTCTGGAGGGGCAGGTTCAGACA 550

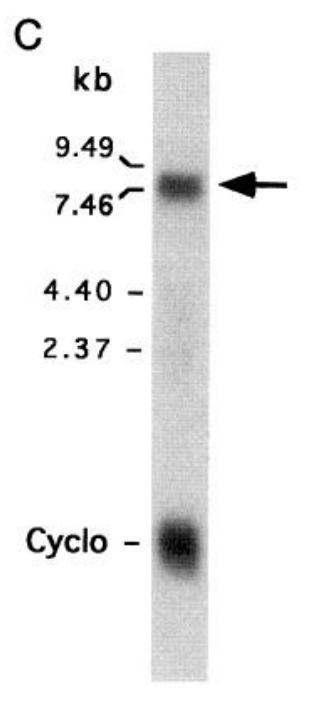

Figure 1. A, Schematic map of the rat $P B X I$ partial cDNA: the hatched bar indicates the cDNA, the top line indicates the location of the sequence encoding the homeodomain $(H D)$, and the letters $(E)$ show the EcoRI restriction sites. $B$, Alignment of rat DNA sequences with the human $P B X 1$. $C$, Northern analysis of newborn ( $\mathrm{P} 0)$ rat brain $P B X 1$ expression showing the specificity of the probe used. The rat cDNA probe hybridized to a single band of $\sim 8 \mathrm{~kb}$ (arrow).

\section{PBX1 mRNA expression in the CNS is temporally and spatially regulated}

Northern analysis of RNA prepared from whole rat brain at various developmental ages (Fig. $2 A$ ) reveals that rat $P B X 1$ mRNA is developmentally regulated. Rat $P B X 1$ expression is detected at the earliest age analyzed, embryonic day 14 (E14), increases by E17, and is most abundant during the first postnatal week (P0-P7). After the first postnatal week, $P B X 1$ expression gradually decreases to the low levels observed in adult brain. To determine the presence and abundance of $P B X 1$ transcripts during the development of the cortical plate, total RNA from cortex at different developmental ages was prepared and analyzed by Northern blot (Fig. 2B). PBXI expression is detected at E14, a time when the proliferating neuroepithelium is beginning to generate neurons destined for the cerebral cortex (Hicks and D'Amato, 1968; Valverde et al., 1989). Later in cortical development, $P B X 1 \mathrm{mRNA}$ is relatively abundant at E17, a period of active neurogenesis, and this level of expression is maintained throughout the first postnatal week. As seen for total brain, $P B X 1$ mRNA expression in the cortex is subsequently downregulated. To determine whether other regions of the brain in addition to the cortex express $P B X 1$, the distribution of $P B X 1$ transcripts in various regions of the rat CNS was analyzed at P7 by Northern blot (Fig. 2C). PBX1 mRNA is most abundant in the olfactory bulb, the interneurons of which are generated postnatally (Bayer, 1983), and is expressed at lower levels in neocortex and midbrain; it is barely detectable in brainstem and cerebellum. Among the nonneuronal tissues tested at this age, little $P B X 1$ is detected, except in kidney (Fig. 2C). 
A

Rat PBX1

\section{Cyclophilin}

B

Rat PBX1

Cyclophilin
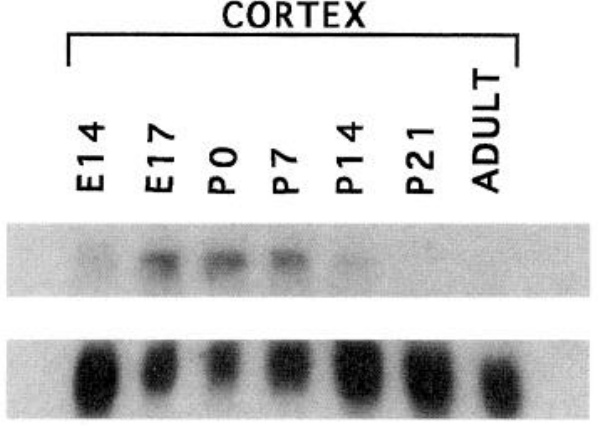

Rat

PBX1

\section{Cyclophilin}

Figure 2. Northern analysis of $P B X I$ expression. $A, P B X 1$ expression in developing rat brain. $P B X I$ mRNA is detected in whole brain at embryonic day $14(E 14)$, peaks in the first postnatal week $(P 0-P 7)$, and then decreases to low levels in the adult. At postnatal day $7(P 7)$ less sample was loaded, as shown by the lower level of cyclophilin mRNA detected. $B$, $P B X 1$ expression in developing cortex. $P B X 1$ is expressed at $E 14$ and $E 17$ in the cortex. Postnatally, $P B X I$ expression in the cortex is prominent during the first postnatal week and is subsequently downregulated. $C$, $P B X 1$ expression in $\mathrm{P} 7$ rat tissues. $P B X 1$ is expressed at very high levels in the olfactory bulb, and at lower levels in the neocortex, midbrain, brainstem, and cerebellum. In non-neural tissues, $P B X 1$ is expressed in kidney, but is barely detectable in liver and spleen.

\section{$P B X 1$ is expressed in regions of active neurogenesis in the developing brain}

To characterize in more detail the expression of $P B X 1$ transcripts in proliferating zones and their target areas in the developing brain, in situ hybridization analysis was performed on rat embryos
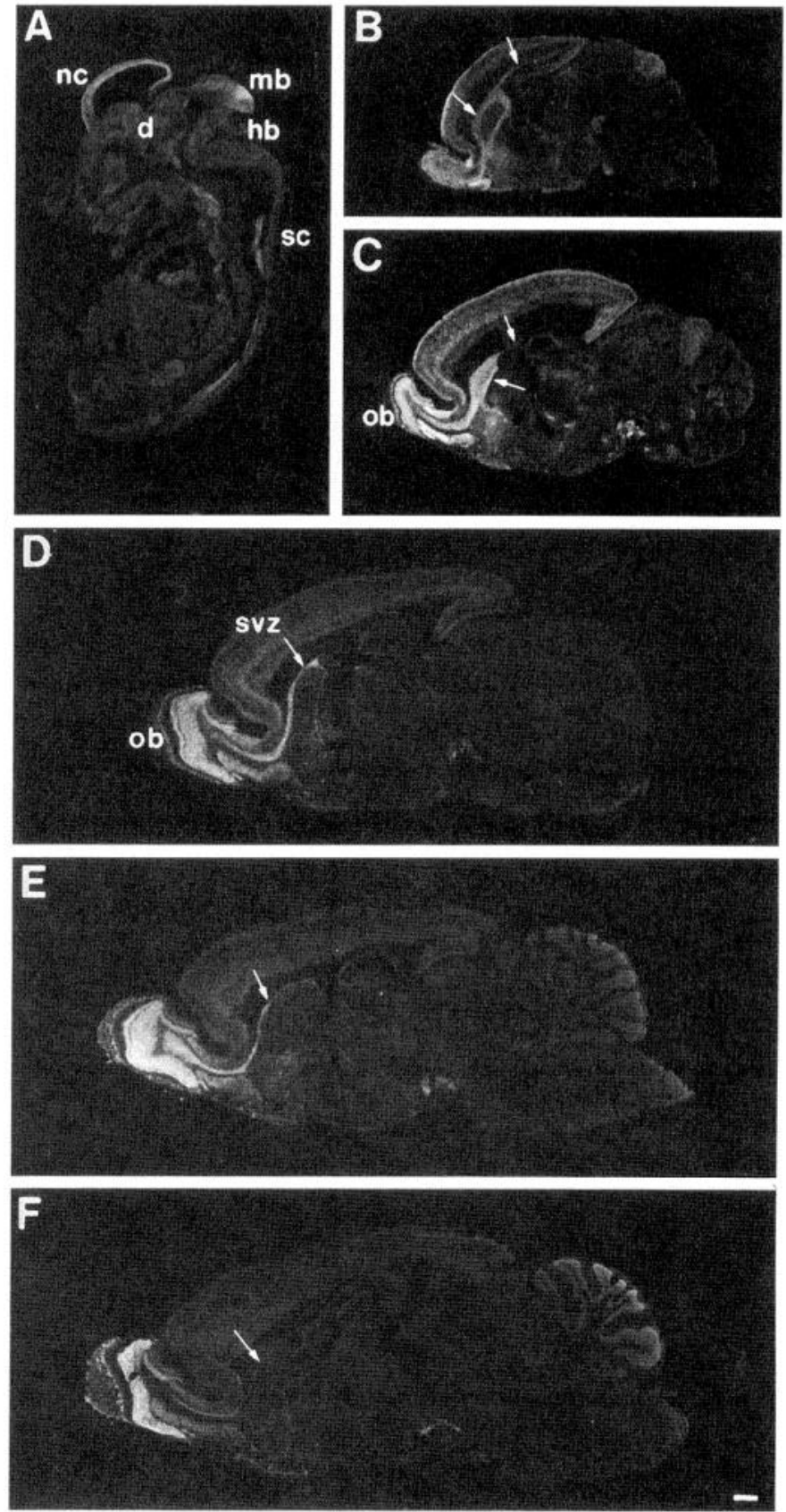

Figure 3. In situ analysis of $P B X 1$ expression in embryonic and postnatal rat brains. Pronounced $P B X 1$ expression at $\mathrm{E} 17(A)$ is seen in the telencephalon and midbrain. Lower levels are detected in the diencephalon, hindbrain, and spinal cord. Expression of $P B X 1$ at P0 $(B), \mathrm{P} 7(C), \mathrm{P} 14(D)$, $\mathrm{P} 21(E)$, and adult $(F)$ is most prominent in the subventricular zone (arrows) and olfactory bulb. Although a high level of expression is maintained in these areas into adulthood, particularly in the olfactory bulb, expression in the neocortex declines after P7. Autoradiograms were used as negatives for prints. $n c$, Neocortex; $m b$, midbrain; $d$, diencephalon; $h b$, hindbrain; $s c$, spinal cord; $s v z$, subventricular zone; $o b$, olfactory bulb. The arrows indicate the subventricular zone and the migratory pathway to the olfactory bulb. Scale bar, $1 \mathrm{~mm}$.

and postnatal rat brain. $P B X 1$ expression was detected at E14 (data not shown) and E17 in the developing telencephalon, midbrain, diencephalon, brainstem, and spinal cord (Fig. $3 A$ ). $P B X 1$ is also expressed at E17 in retina (data not shown). Higher magnification of E17 brain reveals $P B X 1$ expression in the neocortex 

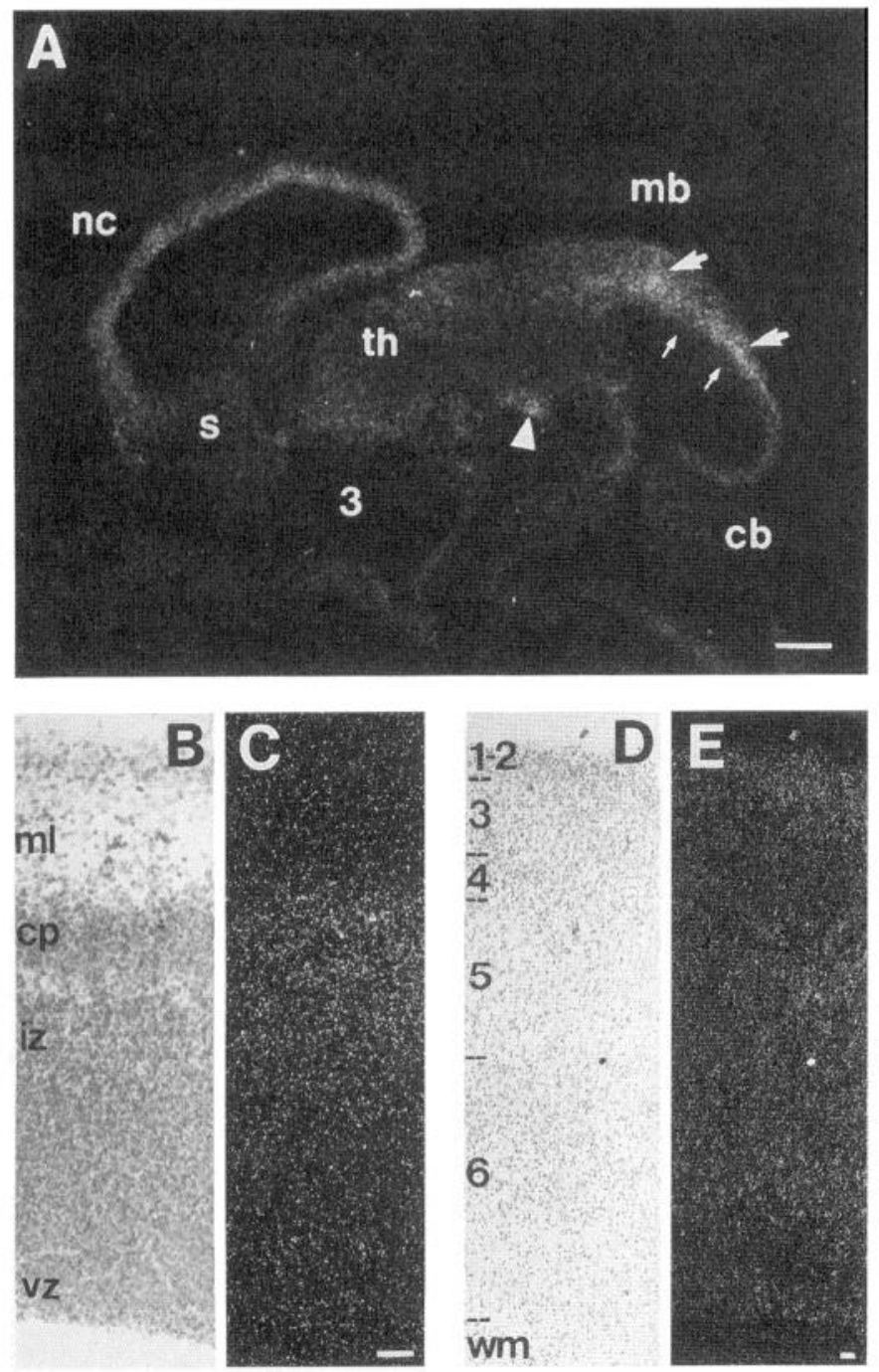

Figure 4. Higher magnification of embryonic brain and embryonic and postnatal rat neocortex in situ hybridization illustrating the regions of $P B X 1$ expression. $A$, At $\mathrm{E} 17 \mathrm{PBX} 1$ expression is observed in the neocortex and is prominent outside of the neuroepithelium (small arrows) of the midbrain (large arrows). PBXI expression is also detected in the ventral tegmental area (arrowhead). Expression of $P B X 1$ in the neocortex at E17 $(C)$ is most prominent in the cortical plate, although expression can be detected throughout the thickness of the cortex. $P B X 1$ cortical expression declines postnatally and at P7 $(E)$ is expressed at a low level, and is enriched in layers 1-2, 5, and 6. Cresyl violet staining of the same sections $(B, D)$ shows relative cell densities. Abbreviations are the same as in the previous figure, with the addition of the following: $c b$, cerebellum; $s$, striatum; $t h$, thalamus; 3 , third ventricle; $c p$, cortical plate; $i z$, intermediate zone; $m l$, molecular layer; $v z$, ventricular zone; $w m$, white matter. Scale bars: $A, 500 \mu \mathrm{m} ; B-E, 50 \mu \mathrm{m}$.

and in the differentiating region of the midbrain, but not in the midbrain neuroepithelium (Fig. 4A). $P B X 1$ expression is also detected in the ventral tegmental area (Fig. $4 A$ ). In non-neuronal tissues, lower levels of $P B X 1$ expression are detected in kidney, lung, and heart (Fig. $3 A$ ). Overall, the embryonic pattern of $P B X 1$ expression corresponds to that observed using a probe derived from a human PBX1 cDNA (Roberts et al., 1995).

Consistent with Northern blot developmental analysis of neocortical RNA, PBX1 expression is relatively abundant at E17 in the developing neocortex (Fig. $4 C$ ), and it declines postnatally (Fig. $4 E$ ). Expression of $P B X 1$ in the neocortex at E17 is most prominent in the forming cortical plate, although expression can be detected throughout the thickness of the telencephalon (Fig. $4 C$ ). At $\mathrm{P} 7 \mathrm{PBX}$ 1 expression can still be detected throughout the cortical plate and is enriched in layers $1-2,5$, and 6 (Fig. $4 E$ ). The lower level of postnatal $P B X 1$ expression detected by Northern analysis and in situ hybridization probably reflects a general downregulation of $P B X 1$ expression, although the presence of a specific population of cortical neurons retaining a relatively high level of expression cannot be excluded. This pattern of expression is consistent with cortical neurogenesis and suggests a role for $P B X 1$ in this process.

\section{$P B X 1$ is expressed postnatally in the SVZ, in the migratory pathway to the olfactory bulb, and in the olfactory bulb layers that are the targets of these neurons}

Postnatally, in marked contrast to the general relative decrease in $P B X 1$ expression in most brain regions (Fig. $3 B-F$ ), $P B X 1$ is expressed at high levels in the SVZ during the first three postnatal weeks (Fig. $3 B-E$ ), a period of active proliferation and differentiation within this region. $P B X 1$ expression is particularly high in the anterior part of the SVZ, where a majority of olfactory interneurons are generated, and along the rostral migratory pathway to the olfactory bulb. The high level of expression observed in the olfactory bulb is consistent with the relatively high level of $P B X 1$ mRNA detected in this region by Northern analysis (Fig. $2 C$ ). This pattern of expression is maintained throughout the first three postnatal weeks and into adulthood (Fig. $3 F$ ), although the highest level of $P B X 1$ expression in the SVZ is apparent during the first postnatal week (P0-P7), a time when a majority of olfactory bulb interneurons are generated (Bayer, 1983). Additionally, $P B X 1$ expression is detected in the ventral tegmental area, piriform cortex, and accessory olfactory bulb.

The temporally and regionally restricted pattern of $P B X 1$ expression in the postnatal rat brain is distinct from that of any previously described transcription factor and suggests that $P B X 1$ plays a role in postnatal neurogenesis of olfactory bulb interneurons. To examine the extent of $P B X 1$ expression along the rostral migratory stream from the SVZ to the olfactory bulb in more detail, serial coronal sections of a P14 rat brain were hybridized with $P B X 1$ antisense riboprobe (Fig. 5). $P B X 1$ is expressed in the SVZ through a large caudal to rostral extent (Figs. 3, 5A-C). Expression is maintained along the rostral migratory stream, where the SVZ becomes rostrally continuous with the subependymal zone of the olfactory bulb (Fig. $5 D, E$ ). PBX1 is highly expressed in the granule cell, mitral cell, and glomerular layers of the olfactory bulb (Fig. $5 F$ ), which constitute the primary destination of cells migrating from the SVZ (Luskin, 1993; Lois and Alvarez-Buylla, 1994). At P14 there is no detectable expression in the embryonically generated neurons of the external plexiform layer (Bayer, 1983) (Fig. 5F). Therefore, the expression of $P B X 1$ in differentiated granule and glomerular layers parallels the cell fate of the neuronal cells generated in the anterior SVZ.

\section{PCNA immunoreactivity coexists with the distribution of PBX1 mRNA in the SVZ and the rostral migratory stream to the olfactory bulb}

To characterize further the population of cells expressing $P B X 1$ in the postnatal SVZ, $P B X 1$ in situ hybridization was combined with immunostaining for a marker of mitotically active cells, the proliferating cell nuclear antigen (PCNA). PCNA is the auxiliary protein of DNA polymerase- $\delta$, and the expression of this G1- and $\mathrm{S}$-phase antigen is indicative of cells actively replicating their 

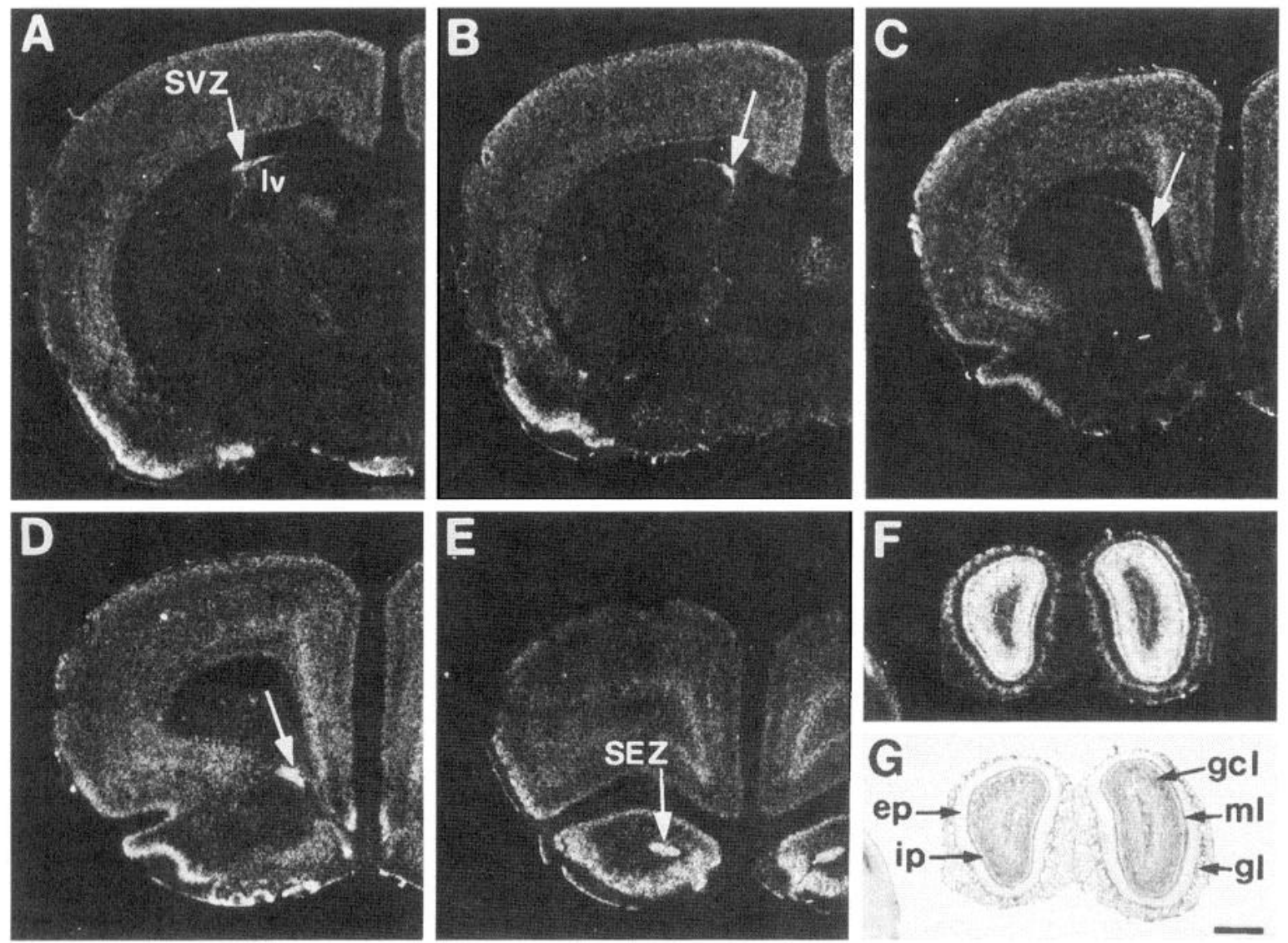

Figure 5. Expression pattern of rat $P B X 1$ in coronal sections of $\mathrm{P} 14$ rat brain. $A-C, P B X 1$ expression is abundant in the subventricular zone as it follows the lateral ventricle throughout a significant caudal to rostral extent of the brain. $D, E$, At more rostral levels, where the subventricular zone becomes continuous with the subependymal zone of the olfactory bulb, $P B X I$ expression is maintained in this pathway. $F$, In the olfactory bulb, expression is detected in layers that are the primary destination of cells migrating from the subventricular zone: the granule cell layer, mitral cell layer, and glomerular layer. $P B X 1$ expression is not detectable in the external plexiform layer. $G$, Same section as in $F$ stained with cresyl violet shows olfactory bulb cell layers and relative cell densities. $S V Z$, Subventricular zone; $l v$, lateral ventricle; $S E Z$, subependymal zone; $g c l$, granule cell layer; $m l$, mitral cell layer; $g l$, glomerular layer; $i p$, internal plexiform layer; $e p$, external plexiform layer. The arrows in $A-D$ indicate the subventricular zone and the migratory pathway to the olfactory bulb. Scale bar, $1 \mathrm{~mm}$.

DNA and undergoing cell division (Miyachi et al., 1978; Mathews et al., 1984; Bravo et al., 1987). Parasagittal sections of P7 rat brain were probed with the rat $P B X 1$ antisense riboprobe, immunostained with an antibody to PCNA, and then processed for autoradiography (Fig. 6A,B). PCNA-immunoreactive nuclei are detected in the SVZ and the rostral migratory stream to the olfactory bulb, consistent with the presence of proliferating precursor cells in these regions (Morshead and van der Kooy, 1992; Lois and Alvarez-Buylla, 1994; Rousselot et al., 1995) Within the SVZ, the distribution of the population of actively proliferating cells, as indicated by PCNA immunoreactivity (Fig. $6 B$ ), is for the most part coexistent with the distribution of $P B X I$ mRNA as detected by in situ hybridization (Fig. $6 A$ ).

\section{TuJ1 but not GFAP immunoreactivity coexists with the distribution of $P B X 1$ mRNA}

During postnatal development, in addition to being a site of neurogenesis, the SVZ is also a major site of gliogenesis (Reynolds and Weiss, 1992; Levinson and Goldman, 1993; Lois and Alvarez-Buylla, 1993; Luskin and McDermott, 1994). To determine whether $P B X 1$ expression in postmitotic cells is limited to neurons or glia, parasagittal sections of $\mathrm{P} 7$ rat brain were hybridized to antisense $P B X I$ and then stained with antibodies that recognize either neuronal (TuJ1) or glial (GFAP) specific antigens.

TuJ1 recognizes class III $\beta$-tubulin, an early marker of postmitotic neurons (Sullivan, 1988; Moody et al., 1989; Lee et al., 1990a,b; Easter et al., 1993). TuJ1 immunoreactivity was detected in the SVZ, along the rostral migratory stream to the olfactory bulb (data not shown), and in the cellular layers of the olfactory bulb that are the target of this migration (Fig. $6 F$ ). In the olfactory bulb (Fig. $6 F$ ), TuJ1 stains the granule cell, mitral cell, and glomerular layers, where postmitotic neurons reside. These are also the layers intensively labeled for rat $P B X I$ mRNA (Fig. $6 E$ ), further supporting the finding that $P B X 1$ expression is maintained in postmitotic neurons derived postnatally from the SVZ.

To verify whether the expression of $P B X 1$ could also be detected in cells of the glial lineage, the white matter overlying the SVZ was analyzed for GFAP and $P B X 1$ double labeling. Both white matter and cortical astrocytes have been shown to originate from progenitor cells in the SVZ (Levison et al., 1993; Luskin and McDermott, 1994). Although TuJ1 immunoreactivity and PBX1 expression overlap in the SVZ of the P7 rat brain, immunoreactivity for GFAP (Fig. 6D), an intermediate-filament protein expressed by glial cells (Eng et al., 1971; Bignami et al., 1972), is not detected in the SVZ and is complementary to the pattern of $P B X 1$ 

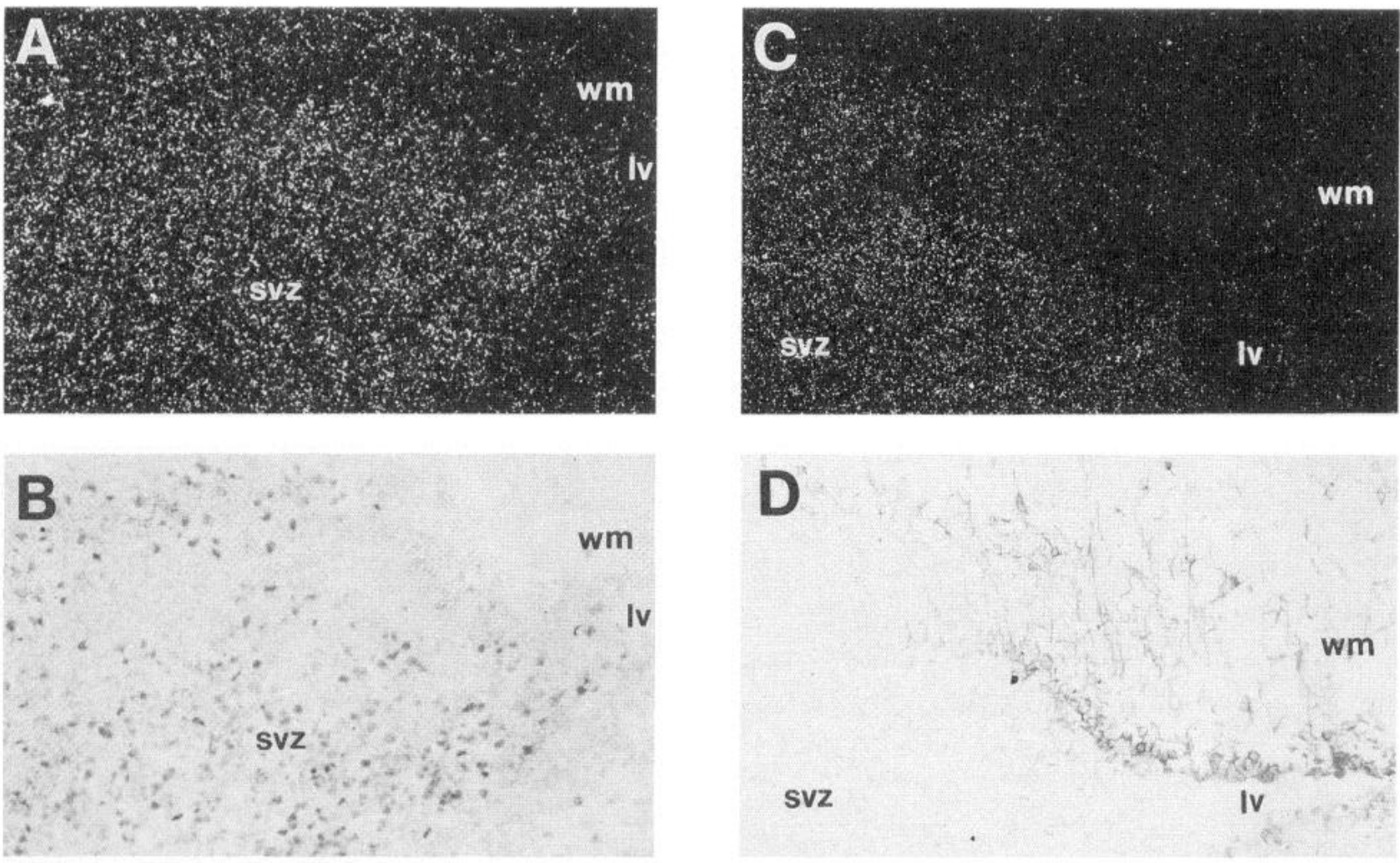

SVZ

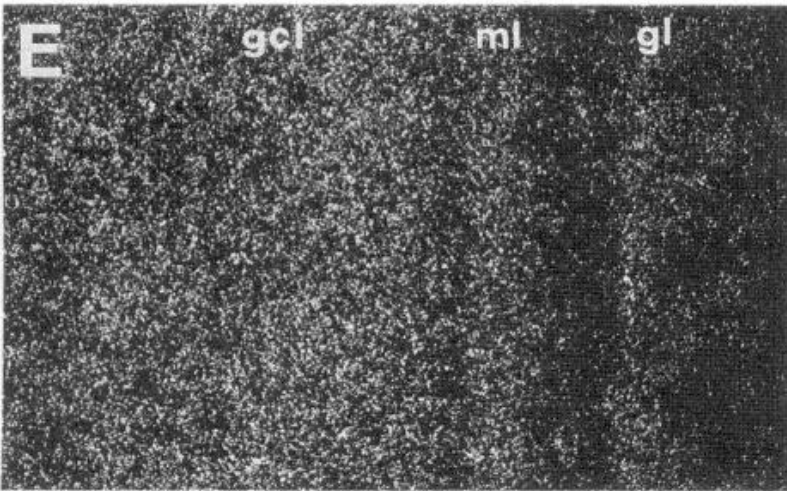

G
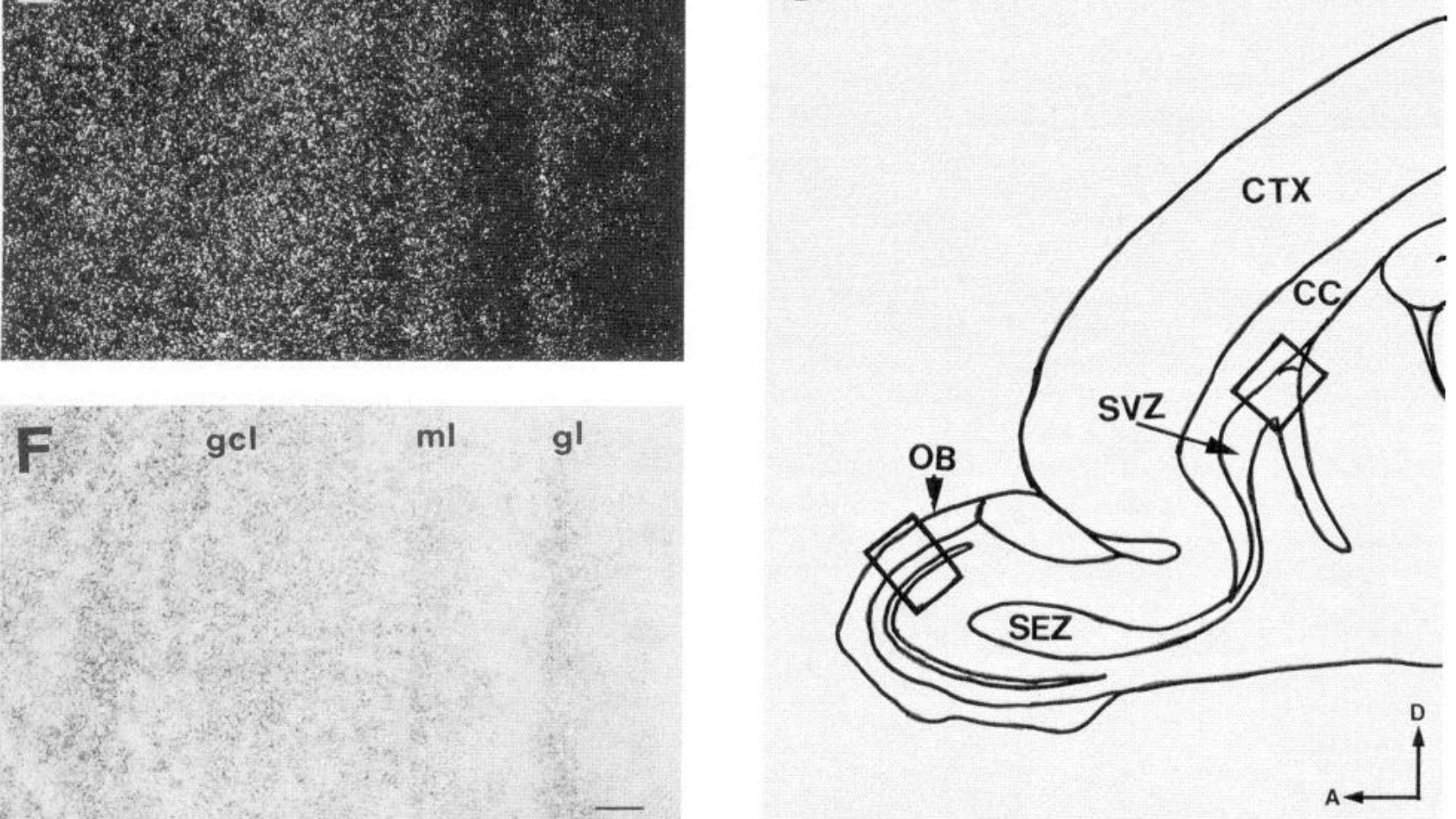

Figure 6. Comparison of in situ hybridization for $P B X 1$ mRNA and immunohistochemistry of $\mathrm{P} 7$ rat brain (parasagittal sections). $A, C, \mathrm{Dark}$-field view of in situ hybridization for $P B X 1 \mathrm{mRNA}$ reveals abundant expression of $P B X 1$ in the SVZ. $B$, PCNA immunostaining of the same section (shown in $A$ ) indicates that PCNA and $P B X I$ expression are overlapping. $D$, GFAP immunostaining of a section hybridized to $P B X 1$ riboprobe (shown also in $C$ ) indicates that GFAP and $P B X I$ label complementary cell populations. $E$, Dark-field view of $P B X I$ antisense probe hybridization in the olfactory bulb. $F$, TuJ1 immunostaining of the same section $(E)$ shows overlapping expression of TuJ1 and $P B X I$ in the granule, mitral, and periglomerular cell layers. $G$, Boxes in a schematic drawing of a P7 parasagittal rat brain indicate the location of upper box $(A-D)$ and lower box $(E, F)$. Abbreviations are the same as in previous figures with the addition of the following: $C C$, corpus callosum; $C T X$, cerebral cortex. Scale bar, $500 \mu \mathrm{m}$. 


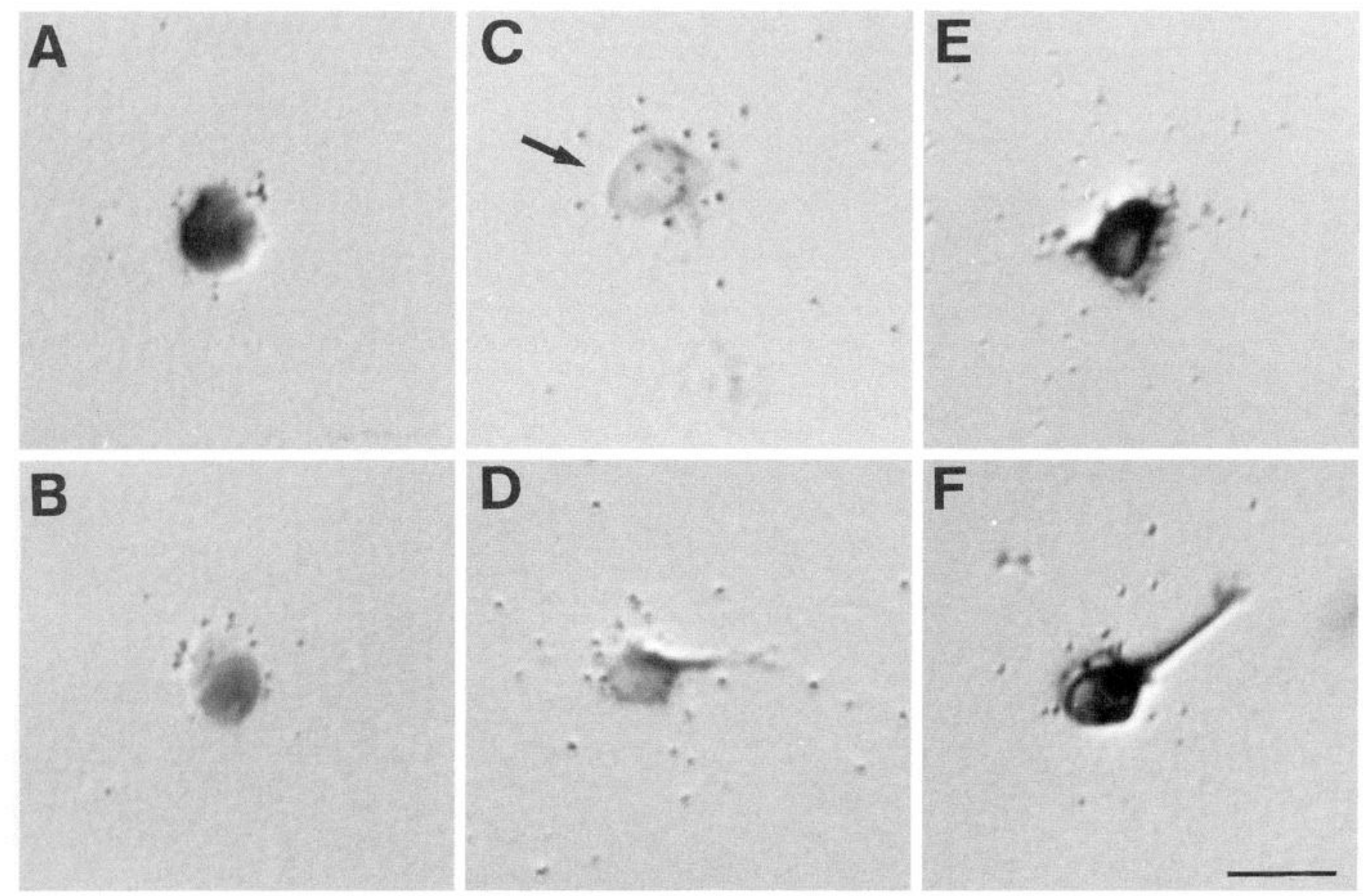

Figure 7. Dissociated cells from $\mathrm{P} 6$ rat brain expressing $P B X 1$ and immunoreactive for PCNA $(A, B)$ and TuJ1 $(C-F)$. $A, B, \mathrm{PCNA}$ is detected in $P B X 1$-expressing cells. Immunoreactivity for PCNA, a nuclear antigen, demonstrates the location of the nucleus. Silver grains from $P B X 1$ hybridization cluster around the perimeter of the nucleus of cells that express both $P B X 1$ and PCNA. $C-F$, Postmitotic neurons expressing PBX1 mRNA and immunoreactive for TuJ1 from the SVZ $(C$, arrow; $D)$ and from the olfactory bulb $(E, F)$. In cells from the SVZ and olfactory bulb, some TuJ1-labeled cells expressing $P B X I$ bear processes ( $D$ and $F$, respectively). Scale bar, $10 \mu \mathrm{m}$.

expression (Fig. $6 C$ ). The possibility that $P B X 1$ is expressed in some glial cells or their precursors cannot be eliminated and, because oligodendrocytes are also generated from the SVZ postnatally, the possibility that $P B X 1$ is expressed in this type of glia cannot be excluded. These results, together with the developmental and regional pattern of $P B X 1$ expression, further support a role for $P B X 1$ in neurogenesis.

\section{$P B X 1$ is expressed in mitotically active precursor cells and TuJ1-immunoreactive neurons}

Because the SVZ is a region rich in precursor cells and in their TuJ1-immunoreactive neuronal progeny, combined in situ hybridization and immunocytochemistry was performed on dissociated SVZ and olfactory bulb cells from P6 rat brain. These experiments show that $P B X I$ is expressed in cells belonging to these two distinct populations. Dissociated cells were processed for in situ hybridization with the antisense rat $P B X 1$ probe and then stained with antibodies to the PCNA, which labels mitotically active cells, or to the neuron-specific antigen class III $\beta$-tubulin (TuJ1). PBX1 expression was detected in cells from the SVZ that also were immunoreactive for PCNA (Fig. 7A,B), as well as in postmitotic neurons from the SVZ and olfactory bulb that were immunoreactive for TuJ1 (Fig. $7 C-F$ ). In SVZ-derived cells, not all cells expressing $P B X 1$ were immunoreactive for PCNA, because PCNA is only expressed during part of the mitotic cycle and, as might be expected if postmitotic neurons express PBXI. Moreover, some cells immunoreactive for PCNA do not express $P B X 1$ (data not shown), suggesting that $P B X 1$ is expressed in only a subset of actively dividing SVZ precursor cells. Similarly, not all SVZ and olfactory bulb cells expressing $P B X 1$ are immunoreactive for TuJ1 (data not shown), consistent with the expression of $P B X 1$ in proliferating cells or those that have not yet acquired a neuronal phenotype. Furthermore, some TuJ1-immunoreactive cells do not express detectable levels of $P B X 1$ (data not shown), suggesting that $P B X 1$ is expressed in a subset of postmitotic neurons. Together these observations indicate that $P B X 1$ is expressed in mitotically active precursor cells and in postmitotic neurons, strongly suggesting a role for $P B X 1$ in neurogenesis.

\section{DISCUSSION}

\section{PBX1 expression in rat postnatal brain is abundant in the SVZ at the time of cell fate determination of olfactory bulb interneurons}

In the postnatal rat brain, $P B X 1$ is expressed in the SVZ, a proliferative region of the forebrain that generates neurons in the postnatal period. The rostral portion of the SVZ contains a subpopulation of proliferating cells that migrate to the olfactory bulb and differentiate into granule and periglomerular neurons (Altman, 1969; Kishi, 1987; Luskin, 1993; Lois and AlvarezBuylla, 1994). We have shown here by in situ hybridization that during the first three postnatal weeks and into adulthood, SVZ 
cells and their progeny express high levels of $P B X 1$ mRNA. Moreover, $P B X I$ expression, both by in situ hybridization and Northern analysis, is highest during the first postnatal week, a time when a majority of olfactory bulb interneurons are generated (Bayer, 1983). Interestingly, the high level of $P B X 1$ expression observed in the $\mathrm{SVZ}$ is also maintained along the rostral migratory stream to the olfactory bulb and in the layers of the olfactory bulh that are the targets of this migration, the granule and glomerular layers. Although a majority of granule cells migrate to the appropriate layer, a subpopulation of displaced granule cells is present in the mitral cell layer (Luskin, 1993). $P B X 1$ expression in this layer may correspond to the displaced granule cells or, alternatively, to the embryonically born mitral cells (Bayer, 1983).

\section{$P B X 1$ expression is associated with PCNA- immunoreactive proliferating precursors cells and TuJ1-immunoreactive postmitotic neurons}

The SVZ is composed of distinct subpopulations of cells including actively proliferating precursor cells as well as postmitotic neurons. It has been suggested that postmitotic neurons in the SVZ, observed using a neuron-specific marker, constitute a distinct population of cells destined to undergo cell death or tangential migration (Menezes and Luskin, 1994). We used an antibody specific for postmitotic neurons ( $\mathrm{TuJ} 1$ ) and one for proliferating cells (PCNA) to determine whether early postmitotic neurons as well as actively dividing cells express $P B X 1$. Our observations of the overlapping distributions of $P B X 1 \mathrm{mRN} \Lambda$ with PCN $\Lambda$ and TuJ1 in tissue sections, and of the double labeling of dissociated cells for $P B X 1$ with PCNA and TuJ1, indicate that $P B X 1$ is expressed by mitotically active SVZ cells (PCNA-immunoreactive) and by TuJ1-positive SVZ and olfactory bulb neurons. The fact that $P B X 1$ is detected in only a subset of PCNA-positive cells suggests that $P B X I$ may be expressed in only a subset of proliferating cells. The precursor cells in the SVZ, therefore, may be a heterogeneous population, possibly reflecting differing commitments to particular cell lineages. In the postnatal SVZ, PCNA-immunoreactive cells expressing $P B X 1$ (and presumably corresponding to proliferating precursors) could represent either the constitutively proliferating subependymal cells or precursors undergoing their last mitosis (Acklin and van der Kooy, 1993; Morshead et al., 1994). Although we did not perform a cell lineage analysis, our data would be consistent with a subset of precursor cells that expresses $P B X 1$ continuing to express this homeobox gene throughout their migration and differentiation into olfactory bulb interneurons.

\section{PBX1 expression is not associated with GFAP-immunoreactive glia}

Several homeobox genes expressed in neurons are also expressed in the glial lineage. For instance, SCIP, a POU homeodomain gene expressed during neurogenesis, is also found in $\mathrm{O} 2 \mathrm{~A}$ progenitor cells of the developing CNS (Collarini et al., 1992; Frantz et al., 1994), and $D L X 2$, another homeobox gene, may also be expressed in the glial lineage (Porteus et al., 1994). Cell fate determination studies of early postnatal and adult subependymal zone have shown that the postnatal SVZ contains precursors of both neuronal and glial lineages (Levinson and Goldman, 1993; Lois and Alvarez-Buylla, 1993). In addition, retroviral studies of neonatal SVZ progenitors indicate that both astrocytes and oligodendrocytes are derived from $S V Z$ precursors, whereas later in development, SVZ cells differentiate preferentially into oligodendrocytes (Levison et al., 1993). Because $P B X 1$ is expressed in the SVZ during the period of gliogenesis, sections from a $P 7$ rat brain were stained for GFAP, an astrocyte-specific marker, to investigate the possibility that $P B X 1$ is also expressed in glia. GFAP- immunoreactive cells in the white matter above the SVZ did not express detectable levels of $P B X 1 \mathrm{mRNA}$. Although we cannot exclude the possibility that $P B X 1$ is expressed in oligodendrocytes or during some stages of gliogenesis, the expression in postmitotic neurons versus the lack of detectable $P B X 1$ expression in GFAPimmunoreactive glia is consistent with a role for this homeobox gene in neuronal cell fate determination.

\section{$P B X 1$ is implicated in postnatal neurogenesis and cell fate determination: possible functions of $P B X 1$}

We have shown here a temporal and spatial pattern of $P B X 1$ expression that parallels neurogenesis and cell fate determination of olfactory bulb interneurons. A more general role in neuronal cell fate determination is possible, because $P B X 1$ expression is not limited to the SVZ. For example, the developmental pattern of $P B X 1$ expression suggests that $P B X 1$ may also play a role in cortical neurogenesis, although a possibly different regulatory role in terminally differentiated neurons is not excluded, given the lower but consistent expression of $P B X 1$ in differentiated cortical neurons. It has been suggested that, in humans, $P B X 1$ might regulate cellular processes such as proliferation, cell death and, possibly, differentiation in the hematopoietic system (Dedera et al., 1993).

Several mammalian homologs of Drosophila homeobox genes have been implicated in determining the regional differentiation of the CNS. Combinatorial interactions among these regulatory proteins have been postulated as one of several mechanisms for regulating gene expression during brain development. The expression of $P B X 1$ in proliferating and postmitotic cells suggests that $P B X I$ expression is maintained in precursor cells as they exit their last cell cycle and start to differentiate into neurons. Cell type-specific combinatorial interactions between $P B X 1$ and other proteins could regulate the expression of distinct sets of target genes controlling diverse patterns of differentiation. This possibility is supported by recent studies showing that the human homeobox gene $P B X 1$ interacts with the Antennapedia class of Hox/HOM proteins, and this interaction modulates their DNA-binding properties (Chang et al., 1995; Neuteboom et al., 1995; Pöpperl el al., 1995; van Dijk et al., 1995; Wilson and Desplan, 1995). Among the homeobox genes expressed in the forebrain, $D L X 2$ is expressed in the postnatal SVZ (Porteus et al., 1994). Although the overall pattern of $D L X 2$ expression is different from that of $P B X 1$, postnatally, DLX2 and PBX1 proteins may coexist in some SVZ cells, perhaps interacting to regulate the expression of genes that control proliferation, cell fate determination, and cell death of these cells.

A majority of cells migrating from the SVZ to the olfactory bulb are immunoreactive for, or closely associated with, an cmbryonic form of the neural cell adhesion molecule PSA-N-CAM (Rousselot et al., 1995). In addition, genetic deletion of N-CAM (Tomasiewicz et al., 1993; Cremer et al., 1994) or enzymatic removal of polysialic acid (PSA) (Ono et al., 1994) results in the accumulation of SVZ cells at the origin of the rostral migratory pathway and in a size reduction of the olfactory bulb attributable to a reduced number of granule cells (Tomasiewicz et al., 1993; Cremer et al., 1994). Interestingly, the promoter of the rat N-CAM gene contains the sequence tTCCATCAA at position - 65 (Chen et al., 1990) that closely resembles the $P B X 1$ consensus binding site (with identical nucleotides in upper case). Previous studies have demonstrated that $P B X 1$ can bind to the consensus sequence AT CA ATCAA to regulate transcription of reporter genes (van Dijk et al., 1993; LeBrun and Cleary, 1994; Lu et al., 1994) (with the invariant nucleotides underlined) (Lu et al., 1994). Although 
a majority of $P B X 1$ target genes are still unidentified, $P B X 1$ could be one of the combinatorial factors regulating the expression of NCAM in SVZ cells and, possibly, determining a state of neuronal differentiation permissive for migration.

\section{REFERENCES}

Acklin SE, van der Kooy D (1993) Clonal heterogeneity in the germinal zone of the developing rat telencephalon. Development 118:175-192.

Altman J (1969) Autoradiographic and histological studies of postnatal neurogenesis. IV. Cell proliferation and migration in the anterior forebrain, with special reference to persisting neurogenesis in the olfactory bulb. J Comp Neurol 137:433-457.

Alvarez-Bolado G, Rosenfeld MG, Swanson I,W (1995) Model of forebrain regionalization based on spatiotemporal patterns of POU-III homeobox gene expression, birthdates, and morphological features. J Comp Neurol 355:237-295.

Bayer SA (1983) ${ }^{3} \mathrm{H}$-thymidine-radiographic studies of neurogenesis in the rat olfactory bulb. Exp Brain Res 50:329-340.

Bignami A, Eng LF, Dahl D, Uyeda CT (1972) Localization of the glial fibrillary acidic protein in astrocytes by immunofluorescence. Brain Res 43:429-435.

Boncinelli E (1994) Early CNS development: distal-less related genes and forebrain development. Curr Opin Neurobiol 4:29-36.

Bravo R, Frank R, Blundell PA, Macdonald-Bravo H (1987) Cyclin/ PCNA is the auxiliary protein of DNA polymerase. Nature 326:515-517.

Chang C-P, Shen W-F, Rozenfeld S, Lawrence HJ, Largman C, Cleary ML (1995) Pbx proteins display hexapeptide-dependent cooperative DNA binding with a subset of Hox proteins. Genes Dev 9:663-674.

Chen A, Reyes A, Akeson R (1990) Transcription initiation sites and structural organization of the extreme $5^{\prime}$ region of the rat neural cell adhesion molecule gene. Mol Cell Biol 10:3314-3324.

Chomczynski P, Sacchi N (1987) Single-step method of RNA isolation by acid guanidinium thiocyanate-phenol-chloroform extraction. Anal Biochem 162:156-159.

Collarini EJ, Kuhn R, Marshall CJ, Monuki ES, Lemke G, Richardson WD (1992) Down-regulation of the POU transcription factor SCIP is an early event in oligodendrocyte differentiation in vitro. Development 116:193-200.

Cremer H, Lange R, Christoph A, Plomann M, Vopper G, Roes J, Brown R, Baldwin S, Kraemer P, Scheff S, Barthels D, Rajewsky K, Wille W (1994) Inactivation of the N-CAM gene in mice results in size reduction of the olfactory bulb and deficits in spatial learning. Nature 367:455-459.

Danielson PE, Forss-Petter S, Brow MA, Calavetta L, Douglass J, Milner RJ, Sutcliffe JG (1988) pIB15: a cDNA clone of the rat mRNA encoding cyclophilin. DNA 7:261-267.

Dedera DA, Waller EK, LeBrun DP, Sen-Majumdar A, Stevens ME, Barsh GS, Cleary ML (1993) Chimeric homeobox gene E2A-PBXI induces proliferation, apoptosis, and malignant lymphomas in transgenic mice. Cell 74:833-843.

Easter Jr SS, Ross LS, Frankfurter A (1993) Initial tract formation in the mouse brain. J Neurosci 13:285-299.

Eng LF, Vanderhaeghen JJ, Bignami A, Gerstl B (1971) An acidic protein isolated from fibrous astrocytes. Brain Res 28:351-354.

Flegel WA, Singson AW, Margolis JS, Bang AG, Posakony JW, Murre C (1993) Dpbx, a new homeobox gene closely related to the human proto-oncogene $p b x 1$. Molecular structure and developmental expression. Mech Dev 41:155-161.

Frantz GD, Bohner AP, Akers RM, McConnell SK (1994) Regulation of the POU domain gene SCIP during cerebral cortical development. J Neurosci 14:472-485.

Gruss P, Walther C (1992) Pax in development. Cell 69:719-722.

Hicks SP, D'Amato CJ (1968) Cell migrations to the isocortex in the rat. Anat Rec 160:619-634.

Jaworski DM, Kelly GM, Hockfield S (1994) BEHAB, a new member of the proteoglycan tandem repeat family of hyaluronan-binding proteins that is restricted to the brain. J Cell Biol 125:495-509.

Kamps MP, Murre C, Sun X, Baltimore D (1990) A new homeobox gene contributes the DNA binding domain of the $t(1 ; 19)$ translocation protein in the pre-B ALL. Cell 60:547-555.

Kishi K (1987) Golgi studies on the development of granule cells of the rat olfactory bulb with reference to migration in the subependymal layer. J Comp Neurol 258:112-124.
LeBrun DP, Cleary ML (1994) Fusion with E2A alters the transcriptional properties of the homeodomain protein PBX1 in $t(1 ; 19)$ leukemias. Oncogene 9:1641-1647.

Lee MK, Rebhun II, Frankfurter A (1990a) Posttranslational modification of class III $\beta$-tubulin. Proc Natl Acad Sci USA 87:7195-7199.

Lee MK, Tuttle JB, Rebhun LI, Cleveland DW, Frankfurter A (1990b) The expression and posttranslational modification of a ncuron-specific B-tubulin isotype during chick embryogenesis. Cell Motil Cytoskeleton 17:118-132.

Levison SW, Chuang C, Abramson BJ, Goldman JE (1993) The migrational patterns and developmental fates of glial precursors in the rat subventricular zone are temporally regulated. Development 119:611-622.

Levison SW, Goldman JE (1993) Both oligodendrocytes and astrocytes develop from progenitors in the subventricular zone of postnatal rat forebrain. Neuron 10:201-212.

Lois C, Alvarez-Buylla A (1993) Proliferating subventricular zone cells in the adult mammalian forebrain can differentiate into neurons and glia. Proc Natl Acad Sci USA 90:2074-2077.

Lois C, Alvarez-Buylia A (1994) Long-distance neuronal migration in the adult mammalian brain. Science 264:1145-1148.

Lu Q, Wright DD, Kamps MP (1994) Fusion with E2A converts the Pbx1 homeodomain protein into a constitutive transcriptional activator in human leukemias carrying the $\mathrm{t}(1 ; 19)$ translocation. Mol Cell Biol 14:3938-3948.

Luskin MB (1993) Restricted proliferation and migration of postnatally generated neurons derived from the forebrain subventricular zone. Neuron 11:173-189.

Luskin MB, McDermott K (1994) Divergent lineages for oligodendrocytes and astrocytes originating in the neonatal forebrain subventricular zone. Glia 11:211-226.

Maniatis T, Fritsch EF, Sambrook J (1989) Molecular cloning: a laboratory manual. Cold Spring Harbor, NY: Cold Spring Harbor Laboratory.

Mathews MB, Bernstein RM, Franza Jr BR, Garrels JI (1984) Identity of the proliferating cell nuclear antigen and cyclin. Nature 309:374-376.

Menezes JRL, Luskin MB (1994) Expression of neuron-specific tubulin defines a novel population in the proliferative layers of the developing tclencephalon. J Ncurosci 14:5399-5416.

Miyachi K, Fritzler MJ, Tan EM (1978) Autoantibody to a nuclear antigen in proliferating cells. J Immunol 121:2228-2234.

Monica K, Galili N, Nourse J, Saltman D, Cleary ML (1991) PBX2 and $P B X 3$, new homeobox genes with extensive homology to the human proto-oncogene PBXI. Mol Cell Biol 11:6149-6157.

Moody SA, Quigg MS, Frankfurter A (1989) Development of the peripheral trigeminal system in the chick revealed by an isotype-specific anti-beta-tubulin monoclonal antibody. J Comp Neurol 279:567-580.

Morshead CM, van der Kooy D (1992) Postmitotic death is the fate of constitutively proliferating cells in the subependymal layer of the adult IIlouse brain. J Neurosci 12:249-256.

Morshead CM, Reynolds BA, Craig CG, McBurney MW, Staines WA, Morassutti D, Weiss S, van der Kooy D (1994) Neural stem cells in the adult mammalian forebrain: a relatively quiescent subpopulation of subependymal cells. Neuron 13:1071-1082.

Neuteboom ST, Peltenburg LT, van Dijk MA, Murre C (1995) The hexapeptide LFPWMR in Hoxb- 8 is required for cooperative DNA binding with $\mathrm{Pbx} 1$ and $\mathrm{Pbx} 2$ proteins. Proc Natl Acad Sci USA 92:9166-9170.

Nourse J, Mellentin JD, Galili N, Wilkinson J, Stanbridge E, Smith SD, Cleary ML (1990) Chromosomal translocation $t(1 ; 19)$ results in synthesis of a homeobox fusion mRNA that codes for a potential chimeric transcription factor. Cell 60:535-545.

Ono K, Tomasiewicz H, Magnuson T, Rutishauser U (1994) N-CAM mutation inhibits tangential neuronal migration and is phenocopied by enzymatic removal of polysialic acid. Neuron 13:595-609.

Pöpperl H, Bienz M, Studer M, Chan SK, Aparicio S, Brenner S, Mann RS, Krumlauf R (1995) Segmental expression of Hoxb-1 is controlled by a highly conserved autoregulatory loop dependent upon exd/pbx. Ccll 81:1031-1042.

Porteus MH, Bulfone A, Liu J-K, Puelles L, Lo L-C, Rubenstein JLR (1994) DLX-2, MASH-1, and MAP-2 expression and bromodeoxyuridine incorporation define molecularly distinct cell populations in the embryonic mouse forebrain. J Neurosci 14:6370-6383.

Rauskolb C, Peifer M, Wieschaus E (1993) Extradenticle, a regulator of homeotic gene activity, is a homolog of the homeobox-containing human proto-oncogene $p b x 1$. Cell 74:1101-1112. 
Reynolds BA, Weiss S (1992) Generation of neurons and astrocytes from isolated cells of the adult mammalian central nervous system. Science 255:1707-1710.

Roberts VJ, van Dijk MA, Murre C (1995) Localization of Pbx1 transcripts in developing rat embryos. Mech Dev 51:193-198.

Rousselot P, Lois C, Alvarez-Buylla A (1995) Embryonic (PSA) N-CAM reveals chains of migrating neuroblasts between the lateral ventricle and the olfactory bulb of adult mice. J Comp Neurol 351:51-61.

Rubenstein JLR, Puelles L (1994) Homeobox gene expression during development of the vertebrate brain. Curr Top Dev Biol 29:1-63.

Sullivan KF (1988) Structure and utilization of tubulin isotypes. Annu Rev Cell Biol 4:687-716.

Tomasiewicz H, Ono K, Yee D, Thompson C, Goridis C, Rutishauser U, Magnuson T (1993) Genetic deletion of a neural cell adhesion molecule variant (N-CAM-180) produces distinct defects in the central nervous system. Neuron 11:1163-1174.
Treacy MN, Rosenfeld MG (1992) Expression of a family of POUdomain protein regulatory genes during development of the central nervous system. Annu Rev Neurosci 15:139-165.

Valverde F, Facal-Valverde MV, Santacana M, Heredia M (1989) Development and differentiation of early generated cells of sublayer VIb in the somatosensory cortex of the rat: a correlated Golgi and autoradiographic study. J Comp Neurol 290:118-140.

van Dijk MA, Voorhocve PM, Murrc C (1993) Pbx1 is converted into a transcriptional activator upon acquiring the $\mathrm{N}$-terminal region of E2A in pre-B-cell acute lymphoblastoid leukemia. Proc Natl Acad Sci USA 90:6061-6065.

van Dijk MA, Peltenburg LTC, Murre C (1995) Hox gene products modulate the DNA binding activity of $\mathrm{Pbx} 1$ and $\mathrm{Pbx} 2$. Mech Dev $52: 99-108$

Wilson DS, Desplan C (1995) Cooperating to be different. Curr Biol $5: 32-34$ 